\title{
The 5th International Innovative Mining Symposium in the year of the 70th anniversary of T.F. Gorbachev Kuzbass State Technical University: rely on traditions, open to the future
}

\author{
Andrey Krechetov ${ }^{1, *}$ \\ ${ }^{1}$ T.F. Gorbachev Kuzbass State Technical University, Rector, 650000, 28 Vesennyaya St., Kemerovo, \\ Russia
}

\begin{abstract}
International Innovative Mining Symposium, being organized on the basis of T.F. Gorbachev Kuzbass State Technical University since 2017 , is meant to promote the growth of fundamental knowledge in the field of mining. That allows comprehensively covering the innovative development of mining and deep processing of minerals, the greening of mining, the modernization of equipment, the introduction of modern means of ensuring labor safety, and the sustainable development of mining clusters. Contributing to the solution of the innovative development problems of the Russian mineral resource complex, the 5th International Innovative Mining Symposium will unite the efforts of representatives of domestic and world mining science and production. This event will help to accelerate the transfer of innovations and adapt foreign experience in the extraction and processing of minerals, involving a wide range of stakeholders in the discussion of labor and environmental protection issues, rational use of natural resources, national energy security.
\end{abstract}

\section{Introduction}

The history of T.F. Gorbachev Kuzbass State Technical University is inextricably connected with the opening of Kuzbass resource storage for Russia and the world, with the development of manufacturing and scientific support for industry development in Western Siberia, with the solution of complex social-and-economic problems [1].

By the time it had been created in 1950, the technical university had the responsibility to provide skilled staff for the transformation of Kuzbass into a highly developed industrial cluster. The latter faced ambitious tasks for the next 20 years:

- to increase the coal production, especially coking, in 4 times;

- to construct new metallurgical plants and create its own ore base for the metallurgical industry;

- to expand the chemical industries;

- to develop its own base of engineering and metalworking industry;

-to create new large power plants and provide self-sufficiency of the region with electricity;

\footnotetext{
*Corresponding author: kuzstu@kuzstu.ru
} 
- to develop light, textile and food industries:

- to accelerate sharply the housing construction.

In 1950, the USSR Council of Ministers decided to open Kemerovo Mining Institute, which was transformed into the Kuzbass Polytechnic Institute in 1965, and in 1993 - into Kuzbass State Technical University. In 2011, it received the name of its founder and the first rector - T.F. Gorbachev.

Over the period of its existence, more than 100 thousand specialists have been trained. They constitute the basis of the engineering staff in the most important sectors of the regional economy; have risen to positions of leadership in resource and energy industries; work in the regional administrations and cities of Kuzbass. Today, six institutes and the faculty of the University, four branches train and retrain those pursuing a graduate degree or beginning a career in 12 programs of specialty, 47 majors for bachelor and 28 for masters, and 135 programs for additional professional education [2]. In 2018, the Institute of Vocational Education was established, where the training is being conducted in 7 secondary vocational programs.

\section{Materials and Methods}

The scientific potential development of the large industrial region of Siberia - Kuzbass was initially entrusted to a technical university, both by attracting scientific staff from other regions, and in the process of establishing its own scientific schools, some of which became truly unique and gained international esteem.

Since the opening of Kemerovo Mining Institute in 1950, its scientists have been actively involved in solving urgent problems of the Kuzbass coal industry: designing and building new mines, mining technology for powerful steeply falling seams, developing open and hydraulic methods for coal mining, introducing mechanization in preparatory and treatment works, safety of miners.

The university departments' staff actively used and is using the achievements of basic sciences in its scientific and research work. Back in the 1970s, the Department of Mining Machines and Complexes using large cleavages created fundamentally new working bodies (mining combines and drilling rigs), which significantly improved technical and economic indicators and reduced dust emission during coal mining. The Department of Automation of Production Processes based on the use of thyristors created automated control systems for drive mining machines, non-static control systems for mine electric locomotives, and automatic troubleshooting devices. The Department of Mining Enterprises Electrification created effective, highly reliable and safe power supply schemes for mines based on the use of vacuum chambers and other modern means.

In the 1980s, the Department of Engineering Technology developed technologies for producing metal with desired properties by electromagnetic impact on metal melts, metal processing with cutters from ceramic-metal and other super-hard materials (for example, albora), heat treatment, as well as automatic program control systems for metal cutting machines were developed.

In the 1980s, a significant result in mining science development in Kuzbass can be considered the working out of method for geodynamic zoning of deposits at the Geodesy Department, which allowed a new planning of mining to be realized at the design and construction stages. This method made it possible to establish a new research area in the field of geometrization of geodynamic processes of the earth's crust. The method of geodynamic zoning was tested in the most geodynamical hazardous areas, and was used to determine the place for new development after the earthquake.

The Kuzbass Scientific School of Geomechanics is widely known. Its scientific experiments and inventions contributed to the development of one of the most difficult 
sections of mining science - the geodynamic manifestations in mines in the form of rock bursts. The conditions and features of their occurrence, nature and the mechanism of manifestation in the zones of tectonic disturbances were identified. That made it possible to increase the safety and efficiency of mining operations, and reduce the loss of coal and ore. Further studies led to the development of a statistical theory of emission processes in loaded structurally heterogeneous rocks. That contributed to designing an automated control system for their destruction, as well as to developing the methods and criteria for determining the degree of rock-bump hazard at separate sections of coal and ore deposits.

In the 1990s, the scientific and educational team of Kuzbass State Technical University created a powerful reserve for the informational support of the educational process. Digital information technology has become a part of all university life. Students and teachers got access to new information, developments of domestic and foreign universities, which allowed optimizing the research process, achieving better results, and effectively promoting the ideas and values of a technical university in the global scientific and educational space.

Since the 2000s the university has more than ten engineering and innovative centers, research laboratories, and a branch of the Thermophysics Institute of the Siberian Branch of the Russian Academy of Sciences. A seismic research site with the most modern equipment was built.

Today, much attention is paid to the development of scientific and technical creativity and research work of undergraduate and graduate students. In accordance with the agreements on scientific and technical cooperation, graduate students, masters and postgraduate students of KuzSTU take an active part in research and expert work conducted by industrial enterprises and companies of Russia and Kuzbass. An important form of development of international relations has become international symposia, conferences, seminars and exhibitions. The university regularly holds them, inviting scientists from Europe and North America, Africa, the CIS and Southeast Asia.

Based on rich traditions, we remember that the university faces the ambitious task of becoming a leading university in the field of training highly qualified personnel for the coal industry. Today T.F. Gorbachev Kuzbass State Technical University is a recognized leader in producing outstanding staff for coal industry in Russia. This is evidenced by the following facts: more than half of all Russian coal miners left the walls of our Alma Mater, about $40 \%$ of managers at Russian coal industry enterprises are also graduates of our university.

At the same time, gaining and maintaining the status of a locomotive of scientific and innovative development of such an industrial cluster as Kuzbass is impossible without an intensive exchange of knowledge and experience with advanced centers of engineering science around the world. The organization of a regular scientific and practical event - the International Innovative Mining Symposium (IIMS) - in 2017 was meant to facilitate this task.

\section{Results and Discussion}

If the first Symposium, held in 2017, immediately attracted the attention of mining scientists from Germany, Turkey, Slovakia, Kenya [3], then by the second Symposium the geography was expanded by the personal participation of representatives from Poland, Belarus, and China. The turning point was the interest in the problems and prospects for the development of Kuzbass coal industry and the international exchange of ideas not only from representatives of foreign universities, but also from industrial companies [4]. In the 2nd International Innovative Mining Symposium the number of guests has grown in five times and exceeded 150 people. 
In 2018, the 3rd International Innovative Mining Symposium became a real industry platform, bringing together more than 300 participants - representatives of the Ministry of Energy of the Russian Federation and the Kemerovo Region Administration, national coal mining companies (SUEK, SDS, EVRAZ, UMMC), professors, undergraduate and graduate students of Russian technical universities, scientists from more than ten countries [5]. The discussion of problems and development prospects of mining clusters took place at eight sites, affected the whole range of relevant research - from mining and processing of minerals and the development of mining engineering directly to solving the social-andeconomic problems of mining areas and advanced development of personnel training for the mining industry.

The 4th International Innovative Mining Symposium, held in 2019, brought together more than 500 participants, including more than 30 foreign guests, in fourteen sections, work sites, round tables, panel discussions and side conferences (Fig. 1).

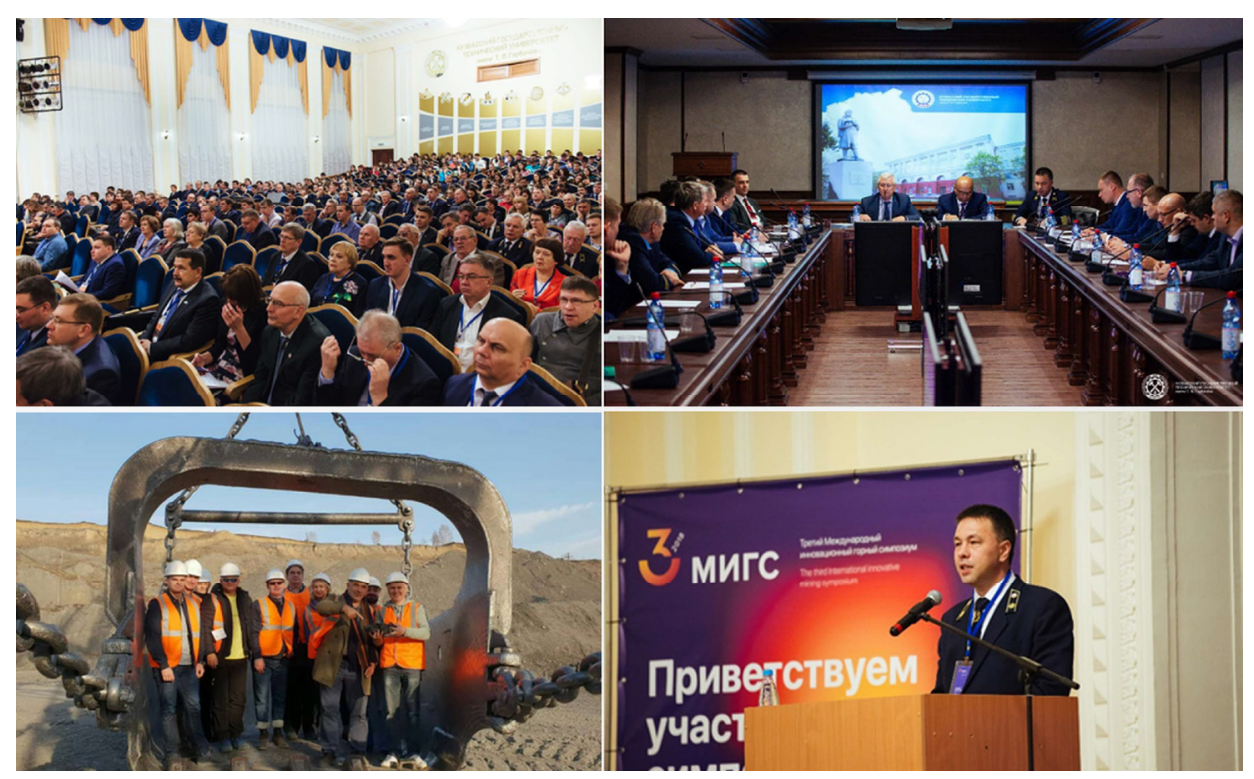

Fig. 1. International Innovative Mining Symposium in pictures.

Regular scientific event has become a good continuation of the traditional collaborative discussion of innovative development issues for mining clusters by Russian and foreign scientists, government and business representatives, university educators and students (Fig. 2). At the 4th Symposium, the tradition of guests' visiting the largest mining enterprises of Kuzbass, objects of introducing the university's scientific achievements into production, was continued. 


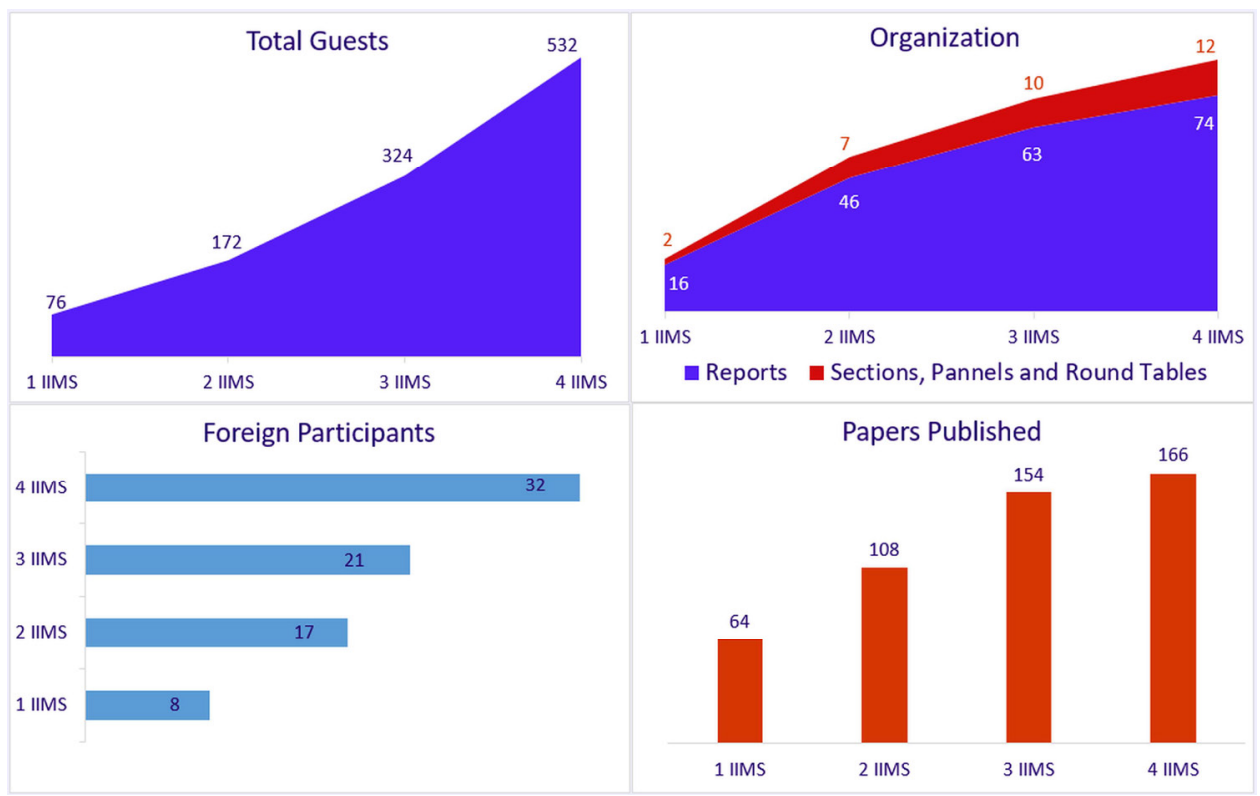

Fig. 1. International Innovative Mining Symposium in numbers.

The participants' scientific papers of each Symposium cover the entire spectrum of discussed issues and are accessible for the world scientific community thanks to the collaboration with the reputable French publisher of scientific literature with a centenarian history - EDP Sciences (E3S Web of Conferences) and indexing in scientific citation databases Scopus (Elsevier) and Web of Science (Thomson Reuters).

\section{Conclusion}

The 5th International Innovative Mining Symposium is faced with the task of promoting the values of T.F. Gorbachev Kuzbass State Technical University in the global scientific and educational space, strengthening its role as a Think Tank of mining science and innovation hub of the regional industrial cluster. To achieve the ambitious goals, it is important to combine the efforts of science and production, Russian and foreign universities in the mineral resource sector, based on the traditions of the mining fraternity and pluralism in discussing the issues of innovative development of mining clusters.

\section{References}

1. A. Krechetov, The role of T.F. Gorbachev State Technical University as the Flagship of Kemerovo Region Innovative Development, E3S Web Conf., 15, 00001 (2017)

2. A. Krechetov, International Innovative Mining Symposium at T.F. Gorbachev Kuzbass State Technical University: To the global "think Tank" of mining science in Kuzbass, E3S Web Conf., 41, 00001 (2018)

3. M. Cehlár, J. Janočko, N. Demirel, S. Anyona, S. Vöth, M. Tyulenev, S. Zhironkin, From Mining Innovations to Sustainable Development: Keynote Speakers of the First to the Second International Innovative Mining Symposium, E3S Web Conf., 21, 00002 (2017) 
4. A. Krechetov, A. Khoreshok, V. Blumenstein, Innovative Competencies of Mining engineers in Transition to the Sustainable Development, E3S Web Conf., 21, 00001 (2017)

5. A. Krechetov, The IIIrd international innovative mining symposium at T.F. Gorbachev kuzbass state technical university as a step to closer cooperation of science, education and business in the mining region, E3S Web Conf., 105, 00001 (2019) 